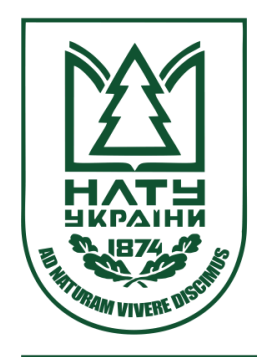

Науковий вісник НЛТУ України Scientific Bulletin of UNFU

https://nv.nltu.edu.ua

https://doi.org/10.15421/40280622

$@ \square$ Correspondence author

Article received 15.06.2018 p.

Article accepted 26.06.2018 p.

B. I. Krivoshey

удк 614.841

\author{
В. В. Присяжнюк1, С. В. Семичаєвський, М. В. Осадчук¹, О. В. Мілютін ${ }^{1}$, Б. І. Кривошей \\ ${ }^{l}$ Украйнський науково-дослідний інститут ичивільного захисту, м. Київ, Украӥна \\ ${ }^{2}$ Національний університет циивільного захисту Украӥни, м. Харків, Украйна
}

\title{
ПЕРЕНОСНІ ЗАСОБИ ДИМО- ТА ТЕПЛОВИДАЛЕННЯ ДЛЯ ПІДВИЩЕННЯ ЕФЕКТИВНОСТІ ГАСІННЯ ПОЖЕЖ ПІДРОЗДІЛАМИ ОРС ЦЗ ДСНС УКРАЇНИ
}

\begin{abstract}
Розглянуто актуальність питання застосування підрозділами ОРСЦЗ ДСНС України переносних засобів димо- та тепловидалення (пожежних димососів). Встановлено, що нагнітання свіжого повітря у приміщення є найефективнішим порівняно з відсмоктуванням загазованого повітря. Зазначено, що застосування комбінованого способу управління газовими потоками за допомогою пожежних димососів дає змогу знизити температурний вплив на людину на основних шляхах евакуації. З'ясовано фактори, що підвищують ефективність гасіння пожеж із застосуванням пожежних димососів. Наведено основні ознаки, за якими класифікують пожежні димососи. Встановлено основні критерії для вирішення питання компоновки переносного засобу димо- та тепловидалення (пожежного димососу). Оптимальні параметри за масою, габаритні розміри та характеристики двигуна буде визначено за результатами аналізу зарубіжних розробок у цій галузі. Наведено порівняння основних технічних характеристик пожежних димососів часів Радянського Союзу із відповідними сучасними зразками, які застосовують у провідних країнах світу. Зазначено потреба виконання науково-дослідної роботи, щоб обгрунтувати технічні вимоги до сучасних переносних пожежних димососів і розробити пропозиції з підвищення ефективності гасіння пожеж з їх застосуванням. Визначено основні завдання, які необхідно вирішити в рамках виконання науково-дослідної роботи.
\end{abstract}

Ключові слова: повітря; технічні параметри; продуктивність; безпечні умови; функціональний макет.

Вступ. Одним із пріоритетних тактичних способів зниження впливу високих температур та диму на особовий склад пожежно-рятувальних підрозділів $є$ керування теплодимовим потоком пожежі за допомогою пожежних димососів, які функціонально призначені для локального підвищення повітряного тиску шляхом нагнітання чистого повітря в зону роботи особового складу, або видалення продуктів горіння 3 приміщень в умовах пожежі для нормалізації температурного і повітряного середовища, щоб забезпечити безпечні умови під час проведення рятувальних робіт. Аналіз оперативно-рятувальної роботи рятувальних служб провідних країн світу свідчить про значну тактичну значущість використання переносних пожежних димососів. Сучасні пожежні димососи, які на сьогодні застосовують рятувальні служби провідних країн світу, $є$ більш маневреними внаслідок їхнього встановлення на колеса, габарити $є$ компактнішими та $є$ можливість їхнього складання, продуктивність 3 нагнітання свіжого повітря становить до 60000-70000 м $3 /$ год. У пожежно-рятувальних підрозділах ДСНС України практично не застосовують пожежні димососи. Для сприяння у вирішенні цієї проблеми в Українському науково-дослідному інституті цивільного захисту розпочато виконання науководослідної роботи, метою якої є обгрунтування технічних вимог до сучасних переносних пожежних димососів і розроблення пропозицій з підвищення ефективності гасіння пожеж з їх застосуванням. Для досягнення поставленої мети в рамках цієї роботи автори планують вирішити такі завдання: проаналізувати інформацію щодо наявності та застосовування пожежно-рятувальними підрозділами провідних країн світу переносних пожежних димососів; проаналізувати нормативно-технічну документацію, зокрема дослідити технічні вимоги до переносних пожежних димососів провідних країн світу; здійснити патентний пошук із зазначеного питання; провести математичний розрахунок технічних параметрів для створення функціонального макету переносного пожежного димососу; обгрунтувати та розробити технічні вимоги до переносних пожежних димососів; створити функціональний макет переносного пожежного димососу; розробити методику проведення експери-

Інформація про авторів:

Присяжнюк Віталій В'ячеславович, начальник відділу. Email: PrisyazhnukV@bigmir.net

Семичаєвський Сергій Валерійович, науковий співробітник. Email: PrisyazhnukV@bigmir.net

Осадчук Максим Віталійович, мол. науковий співробітник. Email: PrisyazhnukV@bigmir.net

Мілютін Олександр Васильович, ст. науковий співробітник. Email: PrisyazhnukV@bigmir.net

Кривошей Борис Іванович, канд. техн. наук, доцент, кафедра інженерної та аварійно-рятувальної техніки. Email: krivoshey63@nuczu.edu.ua; https://orcid.org/0000-0002-2561-5568

Цитування за ДСтУ: Присяжнюк В. В., Семичаєвський С. В., Осадчук М. В., Мілютін О. В., Кривошей Б. І. Переносні засоби димота тепловидалення для підвищення ефективності гасіння пожеж підрозділами ОРС ЦЗ ДСНС України. Науковий вісник НЛтУ України. 2018, т. 28, № 6. С. 113-117.

Citation APA: Prisyazhnuk, V. V., Semichaevsky, S. V., Osadchuk, M. V., Milyutin, O. V., \& Krivoshey, B. I. (2018). Portable means of smoke and heat dissipation to increase the efficiency of fire extinguishing by civil protection operative-rescue service units of the state service of SSES of Ukraine. Scientific Bulletin of UNFU, 28(6), 113-117. https://doi.org/10.15421/40280622 
ментальних досліджень цього функціонального макету та провести експериментальні дослідження. Реалізація науково-дослідної роботи відбудеться шляхом надсилання до підрозділів ДСНС України рекомендацій щодо практичного застосування переносних засобів димо- та тепловидалення.

Постановка проблеми. Більшість випадків травмування та загибелі людей на пожежах відбувається унаслідок впливу на організм небезпечних чинників пожежі. Дія високих температур та диму також значно ускладнюють проведення рятувальних робіт та гасіння пожеж. Вагомим тактичним способом зниження такого впливу на особовий склад пожежно-рятувальних підрозділів $є$ керування теплодимовим потоком пожежі за допомогою пожежних димососів, які функціонально призначені для локального підвищення повітряного тиску шляхом нагнітання чистого повітря в зону роботи особового складу, або видалення продуктів горіння 3 приміщень в умовах пожежі для нормалізації температурного і повітряного середовища, щоб забезпечити безпечні умови під час проведення рятувальних робіт (Sherstiuk, 1972).

Пожежні димососи класифікують (Minaev et al., 1988):

- за призначенням - переносні, причепні, мобільні;

- за типом приводу - механічні, електричні, гідравлічні;

- за принципом роботи - вентиляторні (відцентрові та осьові), ежекторні.

Створити необхідні умови для гасіння пожеж із застосуванням пожежних димососів можна за трьома напрямками (Minaev et al., 1988):

- видалення (відсмоктування) та наступний викид диму назовні (застосовується, як правило, з верхньої частини приміщення);

- нагнітання свіжого повітря до задимленого приміщення (здійснюється, як правило, до нижньої частини приміщення при відкритих верхніх отворах). Цей спосіб застосовують за висоти приміщень до 6 м;

- одночасне видалення задимленого та нагнітання свіжого повітря зі застосуванням декількох димососів. Цей комбінований спосіб застосовують для управління газовими потоками повітря.

На рис. 1 показано схеми установки пожежних димососів на пожежі

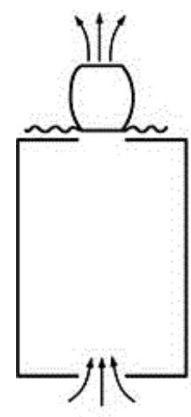

a)

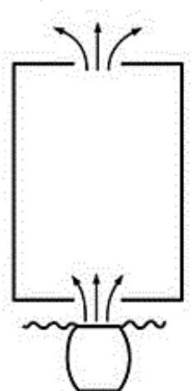

б)

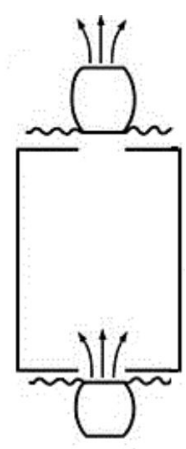

B)
Рис. 1. Схеми установки пожежних димососів на пожежі: а) відсмоктування диму; б) нагнітання диму; в) комбінований спосіб

Аналіз застосування димососів на пожежах показує, що нагнітання свіжого повітря в приміщення $\epsilon$ найефективнішим порівняно з відсмоктуванням загазованого повітря. Так, для димососів 3 продуктивністю $24 \mathrm{~m}^{3} /$ год час видалення продуктів згоряння методом нагнітання на 20-25\% менше, ніж в ролі відсмоктування. Це пояснюють тим, що під час роботи димососу на відсмоктування створюються умови перетікання повітря зі сусідніх приміщень та ззовні, тому димосос разом 3 продуктами згоряння всмоктує значну частину свіжого повітря. Якщо у приміщенні, що горить, концентрація кисню менше а ніж $16 \%$, то застосування пожежних димососів, що працюють на подавання повітря, сприяє іiї підвищенню (Minaev et al., 1988).

Небезпечним для життя людей $є$ також вплив високої температури нагрітих газів і продуктів горіння не тільки у приміщенні, що горить, а і в суміжних 3 ним приміщеннях. Застосування комбінованого способу управління газовими потоками за допомогою пожежних димососів дає змогу знизити температурний вплив на людину на основних шляхах евакуації (Minaev et al., 1988).

За цього виду вентиляції з будівель за допомогою пожежних димососів витісняються продукти горіння i нагріте повітря, при цьому, щоб провітрити все приміщення, потрібно досить небагато часу. Обмін повітря відбувається через різницю в тиску, яке створюється димососом у приміщенні.

Пожежні димососи повинні створювати таку кратність обміну повітря, щоб у міру видалення диму забезпечувалась нормальна концентрація кисню в приміщенні та кількість небезпечних газів знижувалася до безпечних концентрацій (Minaev et al., 1988).

Іншою важливою функцією переносних пожежних димососів $є$ їх використання в ролі засобу для генерації піни високої кратності за використання тактики об'ємного пожежогасіння.

Ефективність гасіння пожеж із застосуванням пожежних димососів зумовлена такими факторами (Minaev et al., 1988):

- покращення видимості у задимленому приміщенні;

- зниження температури;

- зниження концентрації продуктів горіння;

- зменшення ризику поширення пожежі;

- зменшення витрати вогнегасних речовин;

- полегшення проведення рятувальних операцій;

- підвищення ефективності евакуації постраждалих;

- підвищення безпеки роботи пожежно-рятувальних підрозділів;

- зменшення розміру матеріальних збитків.

Аналіз оперативно-рятувальної роботи рятувальних служб провідних країн світу свідчить про значну тактичну значущість використання переносних пожежних димососів, які набули інноваційних змін порівняно із подібними пожежно-технічними засобами часів Радянського Союзу. Сучасні пожежні димососи, які на сьогодні застосовують, наприклад, підрозділи США та європейських країн (останнім часом Російська Федерація теж активно переходить на ці моделі, на відміну від інших країн СНД), істотно відрізняються від радянських аналогів (Minaev et al., 1988). Вони є маневренішими внаслідок їхнього встановлення на колеса, по-друге, габарити димососів $є$ компактнішими та $€$ можливість їхнього складання. По-третє, продуктивність димососу 3 нагнітання свіжого повітря становить до 60000$70000 \mathrm{~m}^{3} /$ год.

На рис. 2 наведено зовнішній вигляд зразків переносних засобів димо- та тепловидалення часів Радянського Союзу, на рис. 3 - зовнішній вигляд сучасних зраз- 
ків переносних засобів димо- та тепловидалення, які є в розпорядженні пожежно-рятувальних підрозділів провідних країн світу.

У таблиці наведено порівняння основних технічних характеристик пожежних димососів часів Радянського Союзу із відповідними сучасними зразками, які застосовують у провідних країнах світу.

Враховуючи наведене вище та той факт, що в пожежно-рятувальних підрозділах ДСНС України практично не застосовують пожежні димососи, актуальним $\epsilon$ питання забезпечення ефективного гасіння пожеж пожежно-рятувальними підрозділами ДСНС України в умовах високої температури та задимленості із застосуванням зазначених засобів.
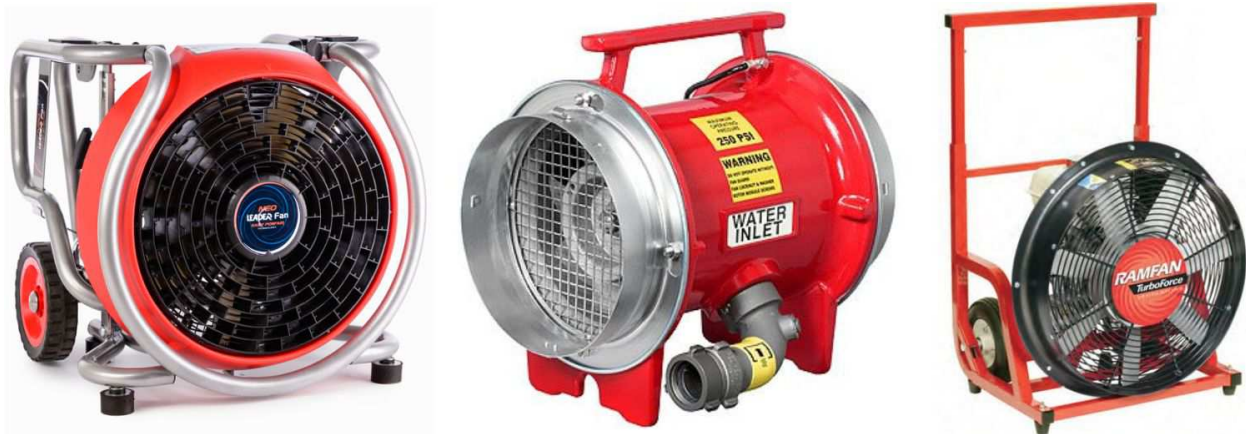

Рис. 3. Зовнішній вигляд сучасних зразків засобів димо- та тепловидалення, які є в розпорядженні пожежно-рятувальних підрозділів провідних країн світу

Таблиця. Порівняння основних технічних характеристик застарілих пожежних димососів часів Радянського Союзу із відповідними сучасними зразками, які застосовують у провідних країнах світу

\begin{tabular}{|c|c|c|c|c|}
\hline \multirow{2}{*}{ Показник } & $\begin{array}{c}\text { ДПЭ- } \\
7\end{array}$ & $\begin{array}{c}\text { ДПМ- } \\
7\end{array}$ & $\begin{array}{c}\text { Leader Fan } \\
\text { ES230 NEO } \\
\text {-230V PPV } \\
\text { (Франція) }\end{array}$ & $\begin{array}{c}\text { Ramfan } \\
\text { GF } \\
\text { 164SE } \\
\text { (США) }\end{array}$ \\
\hline $\begin{array}{l}\text { Продуктивність за по- } \\
\text { вітрям, м/год: } \\
-\begin{array}{l}\text { - з всмоктувальними та } \\
\text { напірними рукавами; } \\
\text { - без рукавів. }\end{array}\end{array}$ & 7000 & 9000 & 27140 & 17099 \\
\hline $\begin{array}{c}\text { Потужність двигуна, } \\
\text { кВт }\end{array}$ & 1,1 & 2,5 & 2,2 & 3,7 \\
\hline Маса в комплекті, кг & 40,5 & 40,0 & 39,3 & 27 \\
\hline
\end{tabular}

Аналіз останніх досліджень і публікацій. У звіті (Prysiazhniuk, 2018) наведено результати досліджень 3 обгрунтування технічних вимог до переносних технічних засобів пожежогасіння, щоб розробити пропозиції 3 підвищення ефективності гасіння пожеж з їх застосуванням підрозділами ОРСЦЗ ДСНС України. Водночас ці дослідження не вирішують питання обгрунтування технічних вимог до переносних засобів димо- та тепловидалення.

Викладення основного матеріалу дослідження. Для сприяння у вирішенні зазначеної проблеми в Українському науково-дослідному інституті цивільного захисту розпочато виконання науково-дослідної роботи, метою якої $є$ обгрунтування технічних вимог до сучасних переносних пожежних димососів i розроблення пропозицій 3 підвищення ефективності гасіння пожеж 3 їх застосуванням.

Для досягнення поставленої мети в рамках цієї роботи автори планують вирішити такі завдання:

- проаналізувати інформацію щодо наявності та застосовування пожежно-рятувальними підрозділами провідних країн світу переносних пожежних димососів для підвищення

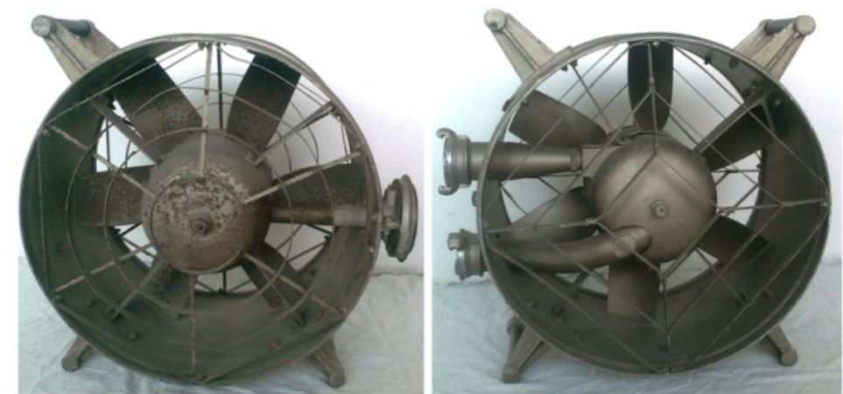

Рис. 2. Зовнішній вигляд сучасних зразків засобів димо- та тепловидалення, часів Радянського Союзу ефективності ліквідації пожеж в умовах високої температури та сильної задимленості;

- проаналізувати нормативно-технічну документацію, зокрема дослідити технічні вимоги до переносних пожежних димососів провідних країн світу та країн СНД, які могли б застосовувати пожежно-рятувальні підрозділи ДСНС України, а також питання щодо тактики застосування цих засобів;

- здійснити патентний пошук із зазначеного питання. Плануємо проаналізувати наявні патенти зарубіжних країн i країн СНД, що стосуються переносних пожежних димососів;

- провести математичний розрахунок технічних параметрів для створення функціонального макету переносного пожежного димососу. В основу буде покладено математичний розрахунок технічних параметрів вентилятора, наведений у звіті (Oreshko et al., 2005). Основними критеріями для вирішення питання компоновки переносного засобу димо- та тепловидалення (пожежного димососу) є: маса установки, габаритні розміри, продуктивність, принцип приводу та характеристики двигуну. Оптимальні параметри за масою, габаритні розміри та характеристики двигуна буде визначено за результатами аналізу зарубіжних розробок у цій галузі (Oreshko et al., 2005);

- обгрунтувати та розробити технічні вимоги до переносних пожежних димососів;

- створити функціональний макет переносного пожежного димососу;

- розробити методику проведення експериментальних досліджень функціонального макету переносного пожежного димососу та провести експериментальні дослідження. Під час проведення експериментальних досліджень будемо брати до уваги вимоги стандартів (NPB 301-2001, 2001; STB 1899-2008, 2008).

Реалізація науково-дослідної роботи відбудеться шляхом надсилання до територіальних підрозділів ДСНС України рекомендацій щодо практичного застосування переносних засобів димо- та тепловидалення та технічних вимог до зазначених засобів до Департаменту ресурсного забезпечення ДСНС України. 
Висновки. Отже, впровадження результатів науково-дослідної роботи надалі сприятиме підвищенню ефективності ліквідації пожеж підрозділами оперативно-рятувальної служби ДСНС України в умовах високої температури та сильної задимленості.

\section{Перелік використаних джерел}

Sherstiuk, A. N. (1972). Nasosy, ventiliatory i kompressory [Pumps, fans and compressors]. Moscow: Vysshaia shkola.

Minaev, N. A., Isaev, M. N., Ivanov, A. F., Konopkin, V. I., Makarov, V. I., Solomonik, Ia. A., et al. (1988). Pozharno-tekhnicheskoe oborudovanie [Fire fighting equipment]. Moscow : Stroiizdat.

Prysiazhniuk, V. V. (2018). Conduct research and develop proposals on the use of portable fire fighting equipment to improve the effectiveness of fire extinguishing. (Report on research work № 0117U008840). The Ukrainian Civil Protection Research Institute.

Oreshko, A. A., Denisevich, O. P., Kaziabo, V. A., \& Shavel Iu. I. (2005). Develop a prototype and organize the production of a portable smoke removal system. Scientific Research Institute of Fire Safety and Emergencies of the Ministry of Emergency Situations of the Republic of Bellaras.

Engineering fire. Smoke exhauster portable firefighters. General technical requirements. Test methods. (2001). NPB 301-2001 from $01^{h}$ September 2001. Moscow: Norms of fire safety of the Russian Federation.

Smoke exhauster portable. General technical requirements and test methods. (2008). STB 1899-2008 from $12^{\text {th }}$ September 2008. State Standard of the Republic of Belarus.

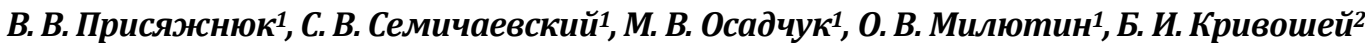 \\ ${ }^{l}$ Украинский научно-исследовательский институт гражданской защиты, г. Киев, Украина \\ ${ }^{2}$ Национальный университет циивильной защиты Украиньл, г. Харьков, Украина}

\section{ПЕРЕНОСНЫЕ СРЕДСТВА ДЫМО- И ТЕПЛОУДАЛЕНИЯ ДЛЯ ПОВЫШЕНИЯ ЭФФЕКТИВНОСТИ ТУШЕНИЯ ПОЖАРОВ ПОДРАЗДЕЛЕНИЯМИ ОСС ГЗ ГСЧС УКРАИНЫ}

Рассмотрена актуальность вопроса применения подразделениями ОРСЦЗ ДСНС Украины переносных средств дымо- и теплоудаления (пожарных дымососов). Установлено, что нагнетание свежего воздуха в помещение является наиболее эффективным по сравнению с отсосом загазованного воздуха. Выяснены факторы, повышающие эффективность тушения пожаров с применением пожарных дымососов. Установлены основные критерии при решении вопроса компоновки переносного средства дымо- и теплоудаления (пожарного дымососа). Приведено сравнение основных технических характеристик пожарных дымососов времен Советского Союза с соответствующими современными образцами, которые применяются в ведущих странах мира. Указана необходимость проведения научно-исследовательской работы с целью обоснования технических требований к современным переносным пожарным дымососам и разработки предложений по повышению эффективности тушения пожаров с их применением. Определены основные задачи, которые необходимо решить в рамках выполнения научно-исследовательской работы.

Ключевые слова: воздух; технические параметры; производительность; безопасные условия; функциональный макет.

V. V. Prisyazhnuk', S. V. Semichaevsky1, M. V. Osadchuk' ${ }^{1}$, O. V. Milyutin'1, B. I. Krivoshey ${ }^{2}$

${ }^{1}$ Ukrainian Scientific Research Institute of Civil Defence, Kyiv, Ukraine

${ }^{2}$ National University of Civil Protection of Ukraine, Kharkiv, Ukraine

\section{PORTABLE MEANS OF SMOKE AND HEAT DISSIPATION TO INCREASE THE EFFICIENCY OF FIRE EXTINGUISHING BY CIVIL PROTECTION OPERATIVE-RESCUE SERVICE UNITS OF THE STATE SERVICE OF SSES OF UKRAINE}

One of the priority tactical methods for reducing the effect of high temperatures and smoke on the personnel of the fire and rescue units is to control the heat drift flux of fire with the help of fire smoke exhausters, which are functionally designed for local increase of air pressure by injecting clean air into the work area of the staff or removing combustion products from premises in the conditions of fire for the normalization of temperature and air environment in order to ensure safe conditions during rescue operations. The analysis of the rescue operation of the rescue services of the world leading countries indicates the considerable tactical significance of the use of portable fire extinguishers. Modern fire extinguishers, which are used by the rescue services of the leading countries of the world nowadays, are more maneuverable due to their installation on wheels, the dimensions are more compact and there is the possibility of their assembly, the capacity for fresh air is up to $60000-70000 \mathrm{~m}^{3} / \mathrm{h}$. In the fire and rescue subdivisions of the SSU of Ukraine, fire extinguishers are practically not used. In order to assist in solving this problem, Ukrainian Civil Protection Research Institute began the implementation of research work, the purpose of which is to substantiate the technical requirements for modern portable fire extinguishers and to develop proposals for improving the efficiency of fire extinguishing with their use. To achieve the goal in the framework of this study, the authors plan to solve the following tasks: to conduct an analysis of information on the availability and use of portable fire extinguishers by the fire and rescue units of the leading countries of the world; to carry out the analysis of the normative and technical documentation, in particular to study the technical requirements for portable fire extinguishers from the leading countries of the world; to conduct a patent search on the given issue; to conduct mathematical calculation of technical parameters for the creation of a functional model of portable fire extinguisher; to substantiate and develop technical requirements for portable fire smoke exhausters; to create a functional model of portable fire extinguisher; to develop a methodology for conducting experimental studies of this functional model and carry out experimental research. The implementation of the research will be carried out by sending recommendations on the practical application of portable means of smoke and heat dissipation to the departments of DSNS of Ukraine.

Keywords: air; technical parameters; productivity; safe conditions; functional layout. 